\title{
MORPHOLOGY AND ETHOLOGY OF THAUMETOPOEA HELLENICA AND THAUMETOPOEA MEDITERRANEA (LEPIDOPTERA NOTODONTIDAE THAUMETOPOEINAE)
}

\author{
(*) Department of Agriculture, Environmental and Food Sciences, University of Molise, Campobasso, Italy \\ $\left(^{\circ}\right)$ Corresponding author: trema@unimol.it
}

Trematerra P., Colacci M. - Morphology and ethology of Thaumetopoea hellenica and Thaumetopoea mediterranea (Lepidoptera Notodontidae Thaumetopoeinae).

Thaumetopoea hellenica and Thaumetopoea mediterranea were recently described from Central Greece and Pantelleria Island (Italy), respectively. In this paper, we reported some information on their morphology, biological cycle and ecology. T. hellenica and T. mediterranea are closely related to T. pityocampa differing mainly in genetic characters. Morphologically, the three species resemble each other, and can be mainly differentiated by observing wing patterns, canthus, and the male and female genitalia. Some data on egg batches, mature larvae, pupae, flight period, host plants and colonized environments were reported.

KeY Words: Thaumetopoea hellenica, Thaumetopoea mediterranea, Greece, Pantelleria Island, morphology, biological cycle, ecology.

\section{INTRODUCTION}

Thaumetopoea hellenica Trematerra and Scalercio, and Thaumetopoea mediterranea Trematerra and Scalercio, were recently described from central Greece and Pantelleria Island (Italy) respectively (TREMATERRA et al., 2017). Specimens were identified by morphological characters and DNA barcoding analysis realized according to HAJIBABEI et al. (2006) and by RATNASINGHAM and HEBERT (2007).

With the aim to provide a contribution to the knowledge of these two species we are reporting new data on their morphology, biological cycle and ecology. Additionally some remarks on morphological characters of the different stages, of the adults phenology, larval activity and food plants are reported.

Investigated localities for T. hellenica and field observations were in Goritsa (Volos) and Ktima Syggrou (Athens) during 2015 and 2016. Goritsa area is a suburban park covered by approximately 120 hectares of pine forest, mainly composed of Pinus brutia Tenore and secondarily of Pinus halepensis Miller. The urban park of Ktima Syggrou area is covered by approximately 65 hectares of pine trees, which in majority are Pinus halepensis (Fig. I).

Investigated localities for $T$. mediterranea and field observations were in Montagna Grande (Pantelleria Island) during 2016 and 2017 at a site with Pinus pinaster Aiton, and in Khaddiuggia site with plants of Cedrus deodara (Roxb.) G. Don. The National Park of Pantelleria extends for about 1,500 hectares. It is mostly covered by the maritime pine, Pinus pinaster. Also very common are reforestations of Aleppo pine, Pinus halepensis and Pinus pinea L. (Fig. VII).

The adults of T. hellenica were mostly found in seven Gtrap pheromone funnel traps (SEDQ, Barcelona, Spain) baited with lures containing $1 \mathrm{mg}$ of the synthetic sex pheromone component (Z)-13-hexadecen-11-ynyl acetate (Trécé Inc., Adair, OK, USA) (ATHANASSIOU et al., 2017).
Data of $T$. hellenica were compared with the same data obtained in the monitoring of Thaumetopoea pityocampa (Den. \& Shiff.), realized in Petacciato area (Central Italy) during 2015 and 2016 using data coming from four G-trap devices.

The adults of $T$. mediterranea were collected with three Mastrap funnel traps (Isagro, Milano, Italy), baited with lures containing $1 \mathrm{mg}$ of the synthetic sex pheromone $(Z)$ 13-hexadecen-11-ynyl acetate (Isagro, Milano, Italy). The data obtained in the study of this species were compared with the observations realized on T. pityocampa collected on Monte Etna, at site of Pitarrona (Sicily) during 2016 and 2017, using data coming from two Mastrap devices.

Additionally, several specimens of T. hellenica and $T$. mediterranea were collected using light traps (160 Watts mixed light).

To provide an overview of the available knowledge related to $T$. hellenica and T. mediterranea, some text already published by TREMATERRA et al. (2017) in the original description of the two species are reported.

\section{Notes on Thaumetopoea hellenica \\ Trematerra and Scalercio, 2017}

DEsCRIPTION - Adult (Fig. II, 1). The male has a wingspan of 30-35 mm, the female is bigger, with a wingspan of $43 \mathrm{~mm}$. Pronounced "canthus" on the front. Wing whitishgrey with three dark-brown transverse bands: basal band small, median band interrupted in the middle and more evident in basal margin, distal band completely darker near costal margin; discocellular spot fairly vague, half-moon shaped, light brown-greyish in colour. Distal spot at apex of wing brown-greyish. Costal area brownish-grey. Cilia brown to light-brown, rather concolorous with markings, brown in basal part, alternate to whitish groups. Hindwings whitishcream with vague anal spot; anal margin with a brownish 

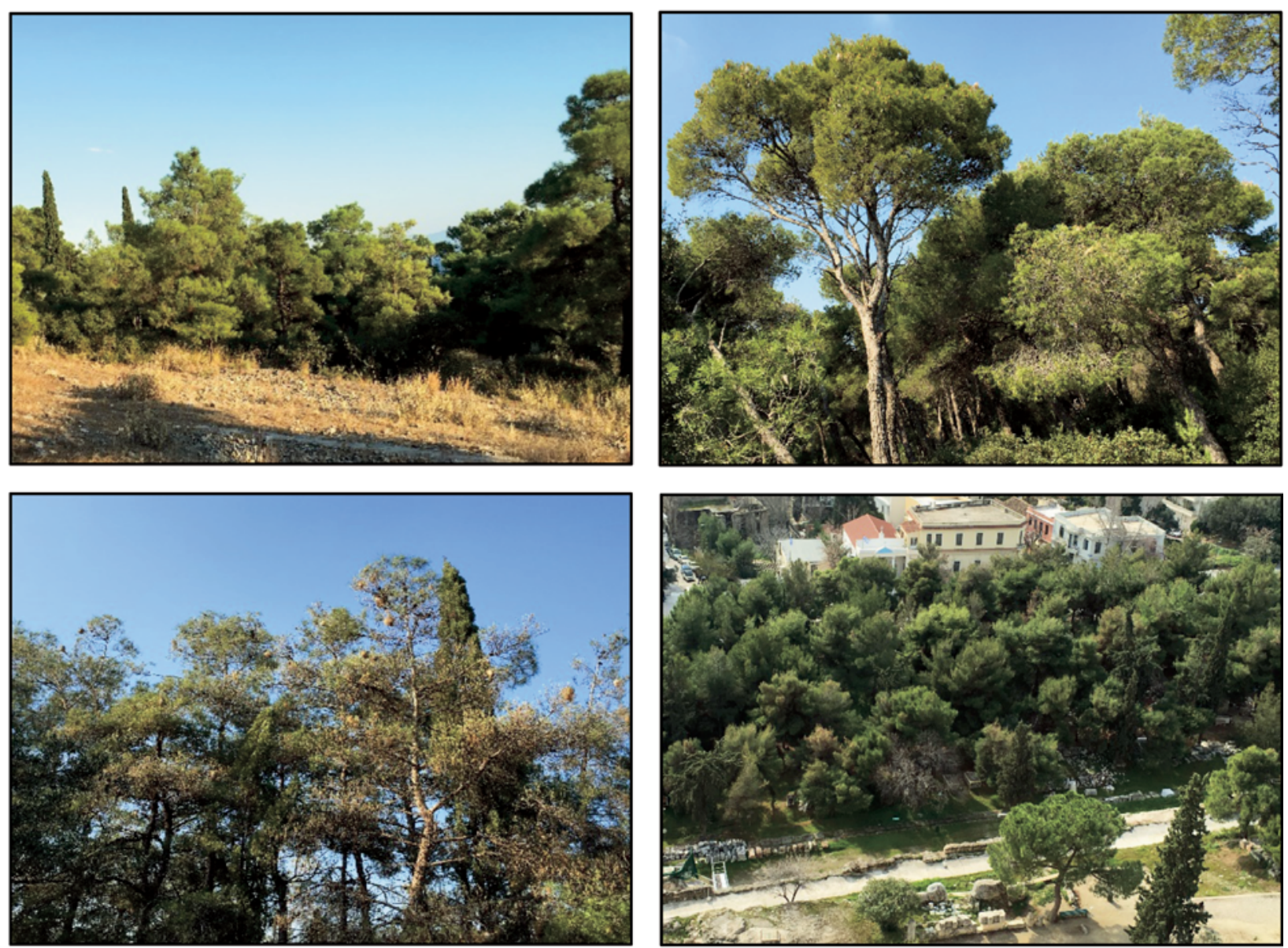

Fig. I - Environments colonized by Thaumetopoea hellenica in Greece.

thin band; fringes whitish-cream. Tuft of hairs, light browncream on internal margin.

FrontAL PROCESS OF MALES (Fig. II, 2) - It has five teeth, one long and four small, and of these the first one is quite pronounced. In frontal view, the bottom four have a different shape. In front of the canthus a developed prominence is present.

Male Genitalia (Fig. II, 3) - Uncus developed, slightly curved, projected forward; socii broad, subtriangular-shaped, twice as long as its width, sickle-shaped. Tegumen broad, constricting towards the apex. Valva subtriangular, elongated, about twice as long as its width, costal margin rather straight slightly concaved at apex; cucullus rounded; ventral edge of valva and sacculus rounded. Aedeagus amphora-shaped, longer than valva, slender, narrow at the distal part; vesica with tip, not margined medially, coecum penis enlarged; juxta subrectangular-shaped, longer than wide, proximal margin hollowed, distal margin rounded. Saccus rather long.

Female Genitalia (Fig. II, 4) - Papillae anales small, apophyses short. Sterigma semi-circular shape narrow, evident and robust, with distal margin concave; subgenital sternite with dense thorns, wide and distally concave. Ductus bursae not sclerotized.

EGG BATCHES (Fig. III) - The egg batches are light brown or greyish, ovum is spherical, whitish and covered with creamy scales. The $21 \mathrm{egg}$ batches studied contained 4,753 eggs, the mean per batch is 226 (range 168-266) eggs. The number of egg-rows per batch varied between 7 and 14; a 1 $\mathrm{cm}$ egg-row contained a mean of 10 eggs. The length of the needles on which eggs were deposited varied between 41 and $112 \mathrm{~mm}$ and the length of the egg batches varied from 19 to $34 \mathrm{~mm}$ (mean $26 \mathrm{~mm}$ ), with a diameter of 3.4-5.5 mm. Most of the egg batches were wrapped around one or two needles, or deposited over small twigs. The distance of the egg batches to the base of the needles varied. In all cases oviposition occurred from base to tip of the needles.

WinterING LARVAE AND NeSTS (Fig. IV and Fig. V, 1 and 2) - The full-grown larva is $30-34 \mathrm{~mm}$ in length. The head capsule is black. In general, the integument is darker in colder areas and varies from dull bluish-grey to black. The lateral and ventral setae vary from white to yellowish. The dorsal setae range from yellowish white to orange and are borne on brown verrucae. The lower part of the body is from brownish to brown.

As in other Thaumetopoea species, also T. hellenica build winter nests on external parts of colonized trees. Nests are especially exposed to the South in the part that receives more sunlight during the winter.

In 2016, the first wintering migrant larvae of $T$. hellenica were observed during the first week of February in Ktima Syggrou (Athens) and two weeks later at Goritsa (Volos) when the temperature was high enough. The latest processions were observed on March 20 at Goritsa and on March 26 at Ktima Syggrou. In both localities the highest number of larvae was recorded from the end of February to midMarch (COLACCI et al., 2018). 
Fig. II - Thaumetopoea hellenica: adult (1); frontal process of male (canthus) (2); male genitalia (3); female genitalia (4).
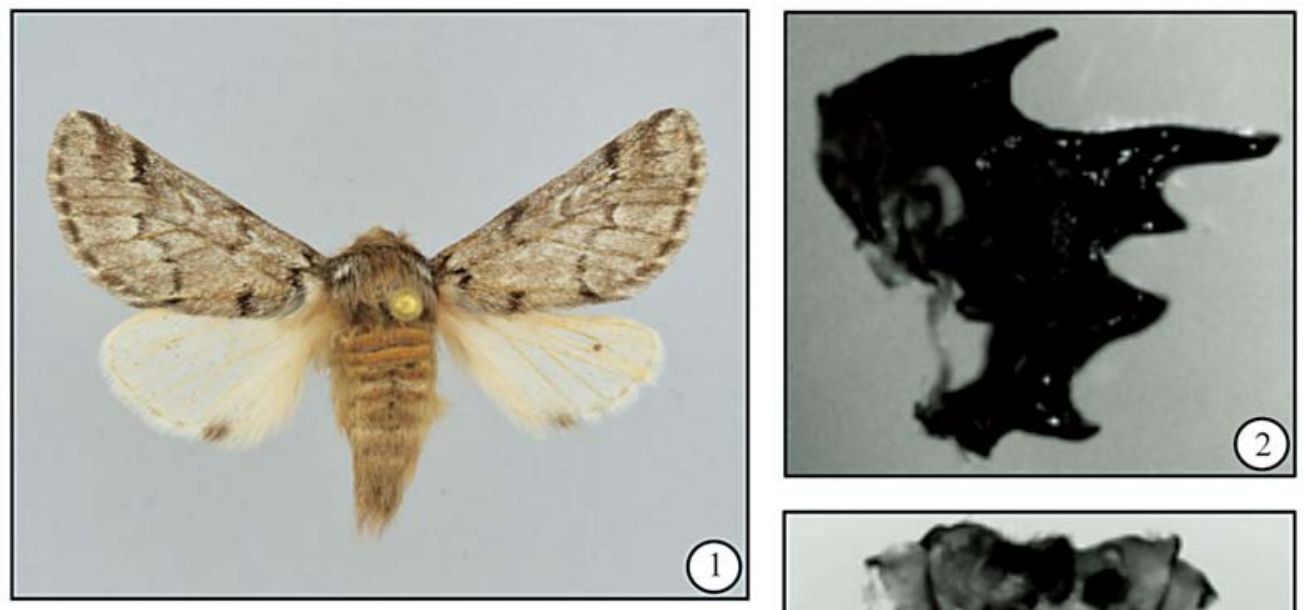

(1)
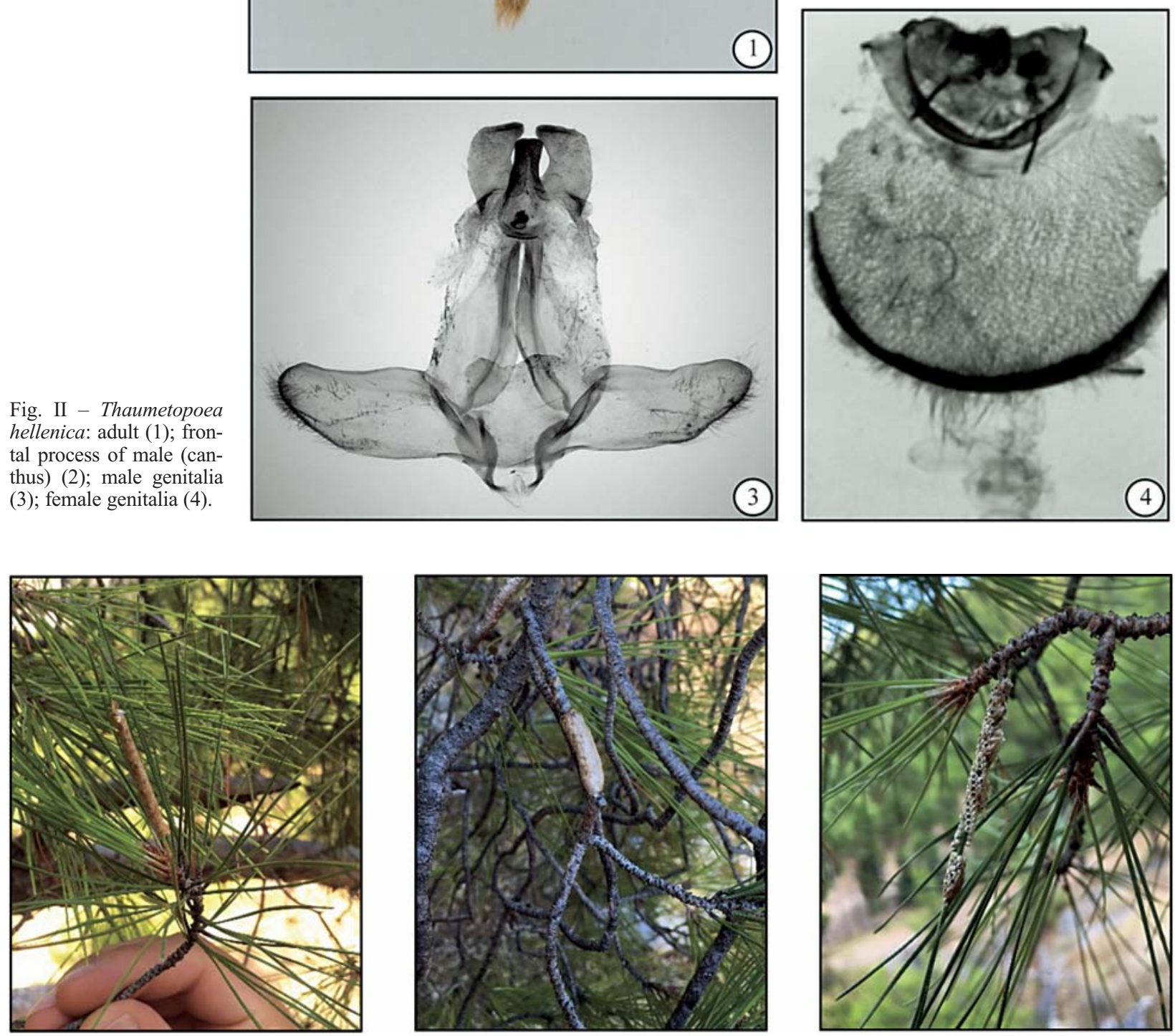

Fig. III - Thaumetopoea hellenica: egg batches.

PuPA (Fig. V, 3 and 4) - The pupa is formed in an oval silk cocoon, below ground, and is of a brownish-white colour. The obtected pupae are about $15-19 \mathrm{~mm}$ in length, oval, and of a pale brownish-yellow colour that later changes to dark reddish-brown. The cremaster is bluntly rounded, with two curved spines.

Flight ACTIVITY OF ADULTS (Fig. VI) - In Goritsa a total of 796 male adults were captured in the pheromone trap devices, during 2015. T. hellenica males started flying in early August (11 August) and ended in the fall in October.
The highest number of adults was recorded during late August and mid-September. In Ktima Syggrou a total of 604 adults were captured in the pheromone trap, during 2015. The flight period of males was initiated in late August (25 August) and lasted until early November (10 November). The highest number of adults was recorded during early September, but captures were relatively high from early September and the following weeks till late September. In contrast, during October until the end of the monitoring period in November, captures were extremely low. 

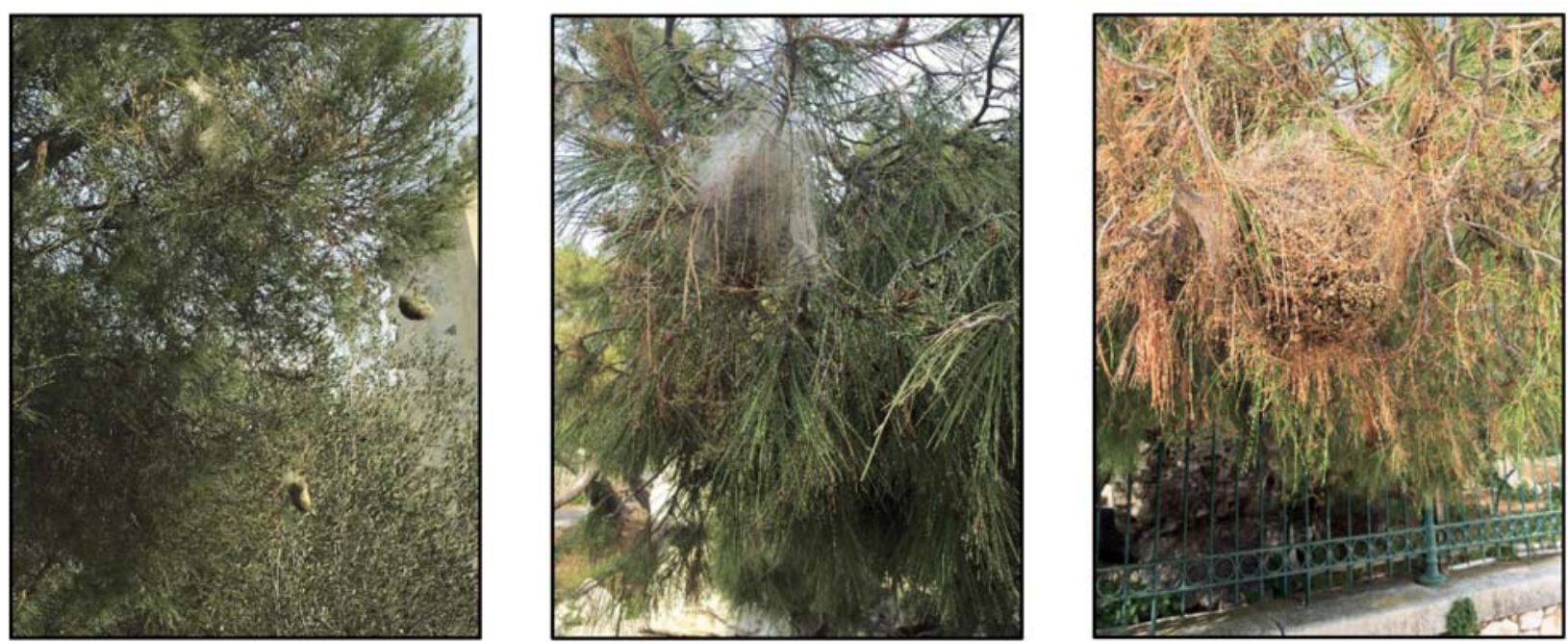

Fig. IV - Thaumetopoea hellenica: winter nests.
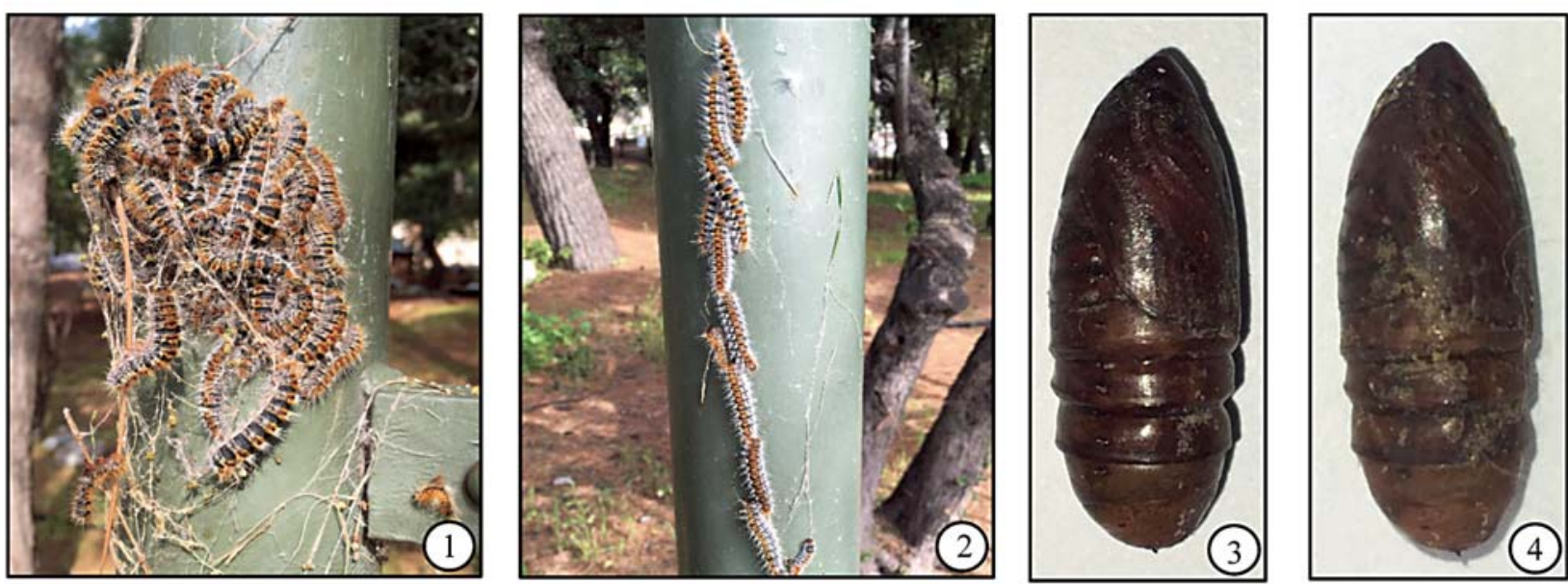

Fig. V - Thaumetopoea hellenica: wintering migrant larvae (1 and 2); pupae (3 and 4).

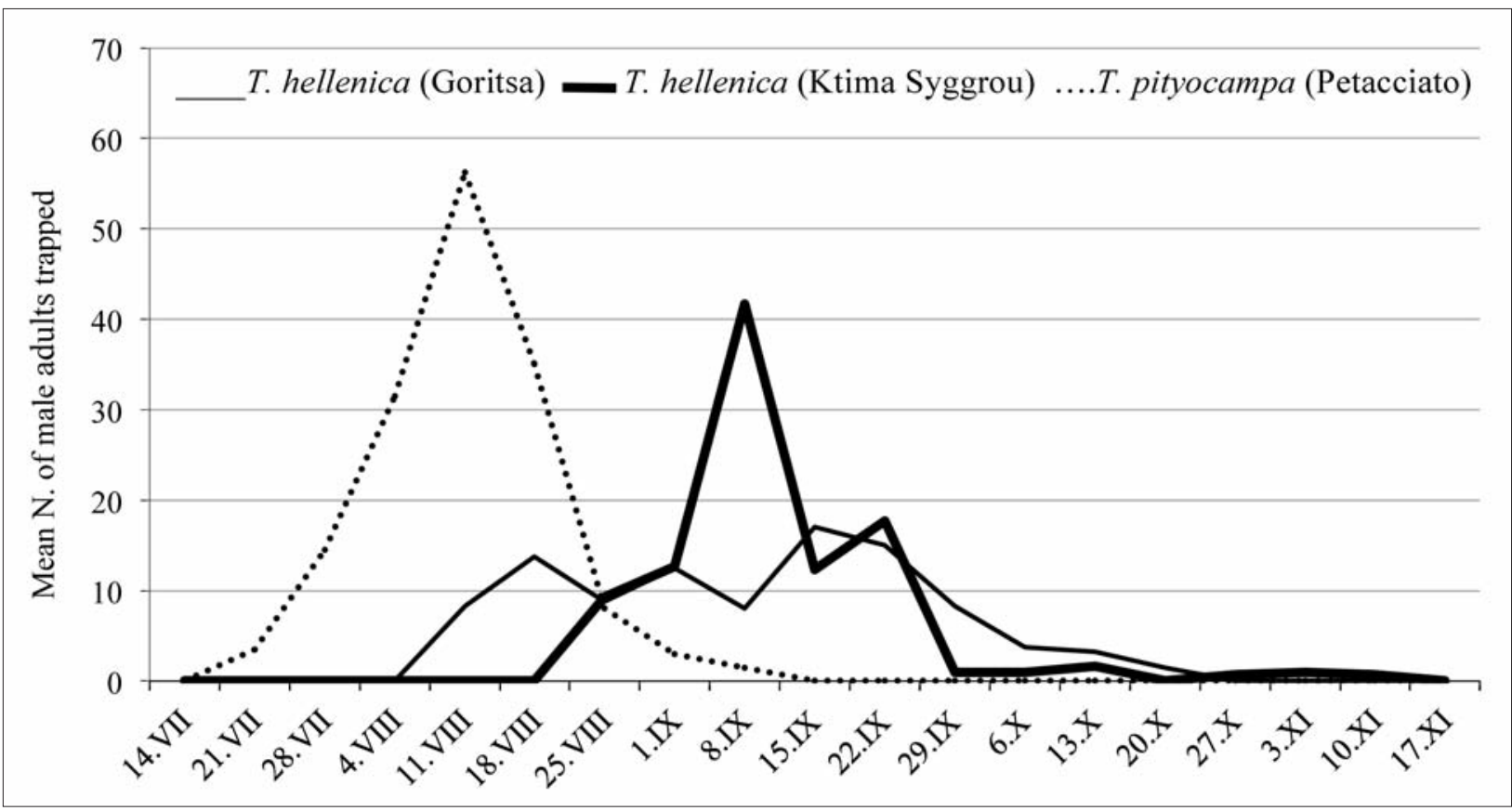

Fig. VI - Flight activity of male adults of T. hellenica in Goritsa and Ktima Syggrou (Greece); flight activity of male adults of T. pityocampa at Petacciato (Italy). 

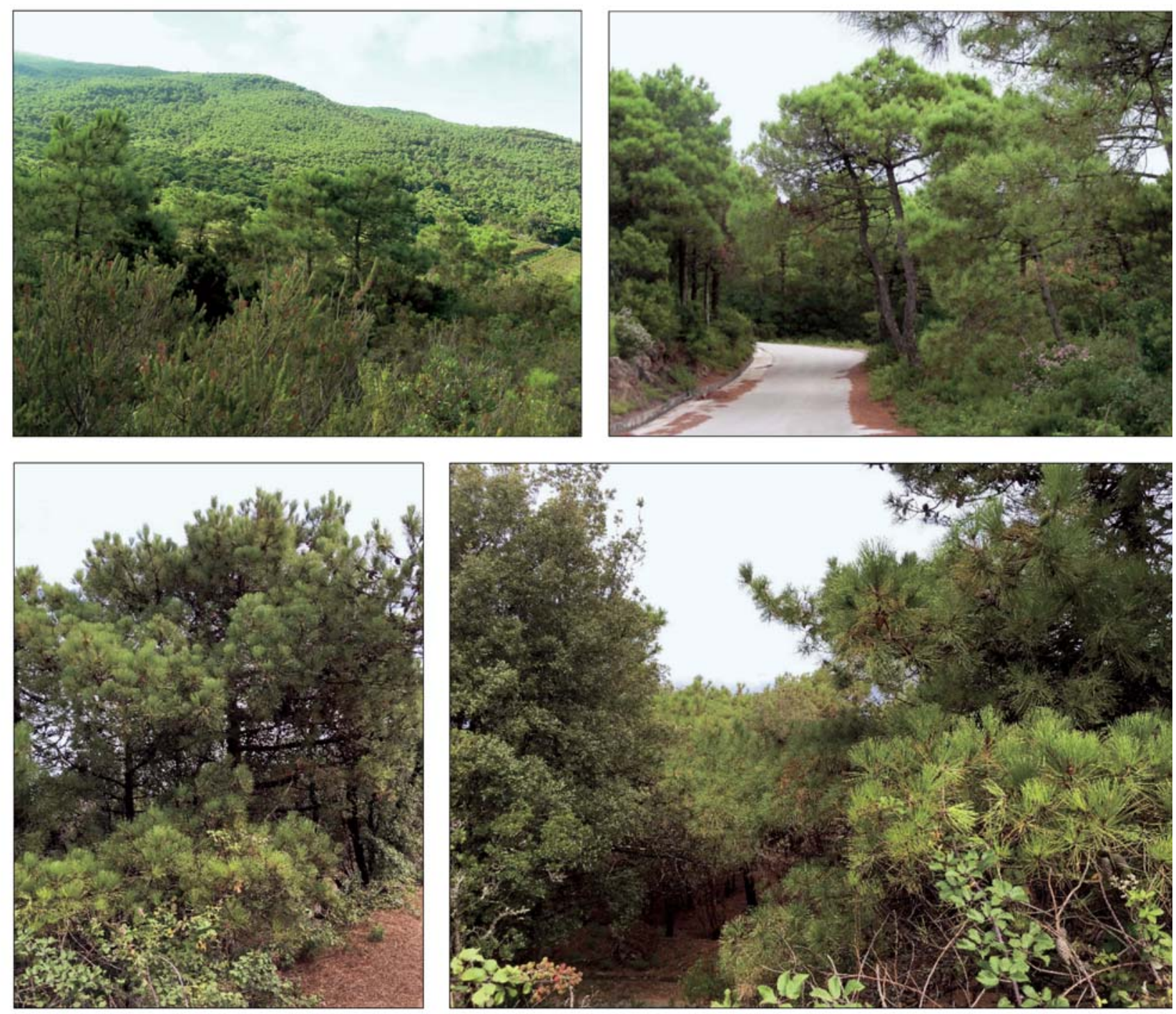

Fig. VII - Environments colonized by Thaumetopoea mediterranea in Pantelleria Island (Italy).

\section{Notes on Thaumetopoea mediterranea}

Trematerra and Scalercio, 2017

DESCRIPTION - Adult (Fig. VIII, 1). The male moth has a wing-span of $30-35 \mathrm{~mm}$, the female is bigger, with a wingspan of $41 \mathrm{~mm}$. Scales on scapus and fronts, light brown; thorax blackish-brown, light-brown, with two lateral clear tufts; the abdomen is brushy and sharp, blakish-brown with light brown scales. Male and female both have a very pronounced canthus on the front. The antennae appear pectinate and bipectinate, light brown from the base to the tip. Wing basal colour whitish grey with three blackish transverse thin bands: basal band small, median band complete, distal band complete darker near costal and anal margins; discocellular spot evident, dark-brown/black, arrow shaped. Spot between basal band and median bands evident. Distal spot at apex of wing blackish-brown. Distal part of wings suffused of dark brown/black scales. Costal margin black, costal area blackish. Cilia dark-brown, rather concolorous with markings, alternate to whitish cilia. Wing veins dark-brown. Hindwings whitishcream, suffused brownish in distal margin, evident black analspot; anal margin with a blackish band; fringes withishcream, blackish at base. Wing veins of honey colour. Long tuft of hairs, light-brown-cream, on internal margin.
Frontal process of MALES (Fig. VIII, 2) - Frontal processes of males (canthus) of T. mediterranea is reported in figure VIII, 2. Front with a process having special appearance, it has six teeth one long and five small, of these the first is very small the four that follow the more pronounced have a similar shape, in frontal view as seen figure VIII, 2.

Male genitalia (Fig. VIII, 3) - Uncus developed, slightly rounded, projected forward, its top with two thorns; broad gnathos, subtrapezoidal-shaped, longer than wide, earshaped. Tegumen broad, constricting towards the apex. Valva subtrapezoidal, elongated, one half as long as its width, costal margin rather straight slightly concaved at apex; cucullus slightly rounded; ventral edge of valva and sacculus rounded with an angle. Aedeagus longer than valva, slender, narrow in the distal part; vesica with tip, immarginated medially, coecum penis enlarged; juxta subrectangular-shaped, wider than long, proximal margin hollowed, distal margin rounded. Saccus rather long.

Female Genitalia (Fig. VIII, 4) - Papillae anales small, apophyses short. Sterigma large, broad, with well developed sinuous anteostial part; subgenital sternite is covered with 

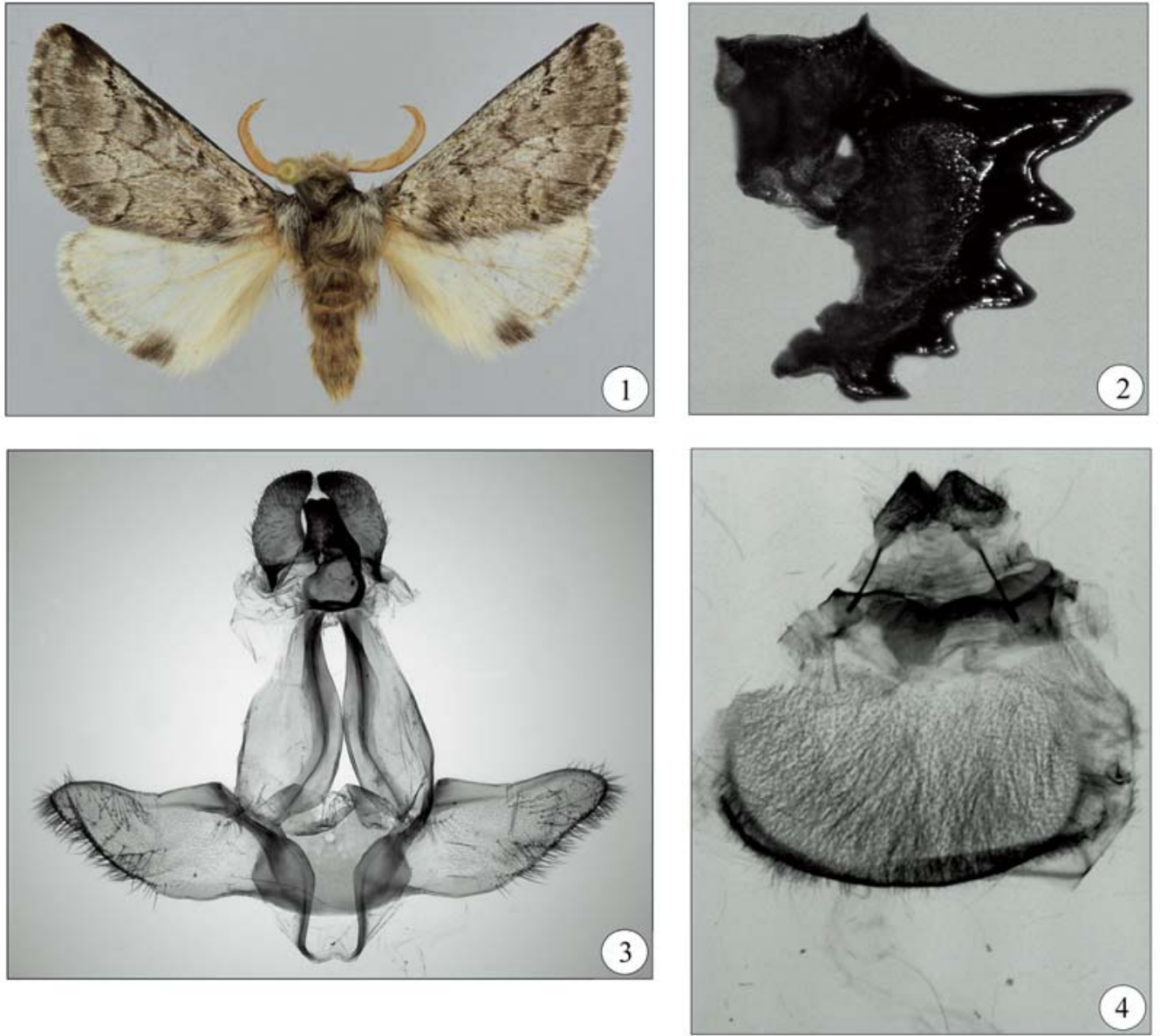

Fig. VIII - Thaumetopoea mediterranea: adult (1) frontal process of male (canthus) (2); male genitalia (3); female genitalia (4). dense thorns and thin bristles, wide and distally concave. Ductus bursae not sclerotized.

EGG BATCHES (Fig. IX, 1) - The egg batches are light brown or greyish, ovum is spherical, whitish and covered with scales. The 18 egg batches studied contained 3,525 eggs, the mean per batch being 195 (range 171-195) eggs. The number of egg-rows per batch varied between 7 and 14; a $1 \mathrm{~cm}$ egg-row contained a mean of 10 eggs. The length of the needles on which eggs were deposited varied between 62 and $105 \mathrm{~mm}$ and the length of the egg batches varied from 28 to $30 \mathrm{~mm}$, with a diameter of 3.5-5 mm. Most of the egg batches were wrapped around one or two needles, or deposit- ed over small twigs. The distance of the egg batches to the base of the needles varied.

Wintering LaRVAe AND Nests (Fig. IX, 2 and X) - The full-grown larva is $30-37 \mathrm{~mm}$ in length. The head capsule is black. In general, the integument is darker in colder areas and blackish in ground colour. The lateral band is whitish grey. The dorsal surface with tufts of whitish yellow to orange setae and red setae on reddish-brown verrucae. The lower part of the body is from brownish to brown.

As in other Thaumetopoea species, T. mediterranea also builds nests on external parts of colonized trees. Nests are especially exposed to the South in the part that receives more
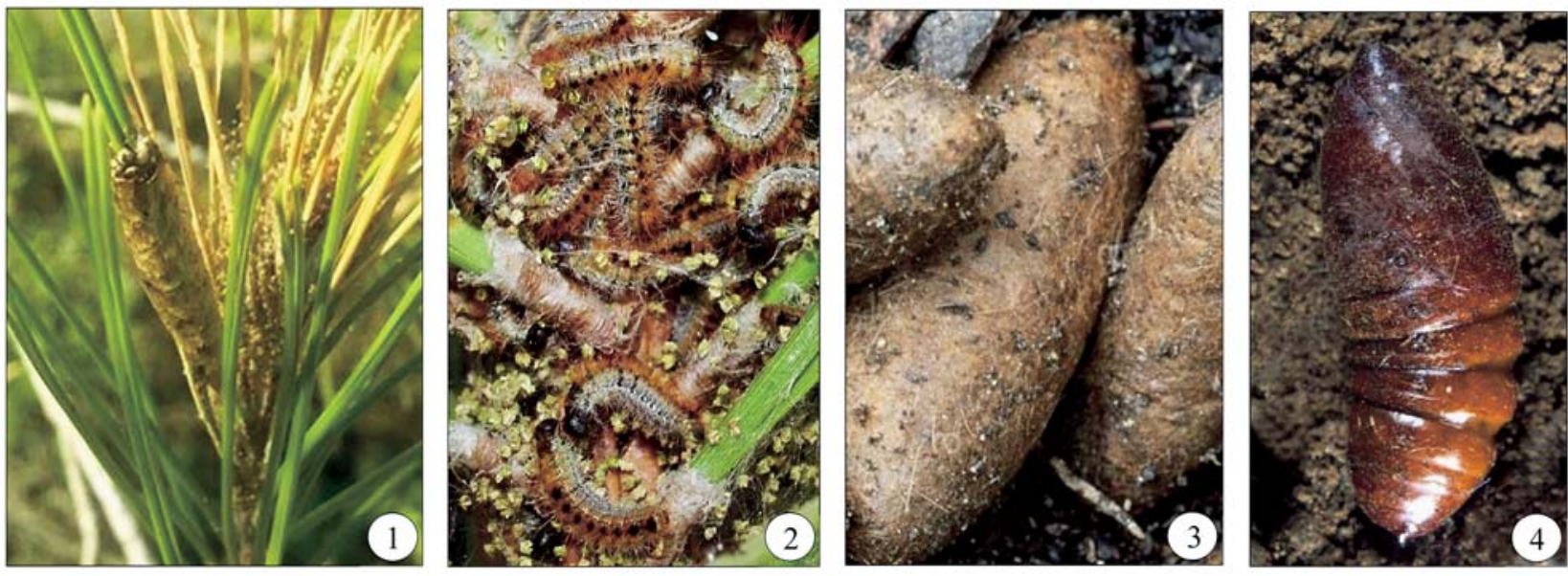

Fig. IX - Thaumetopoea mediterranea: egg batches (1); mature larvae (2); cocoons (3); pupa (4). 

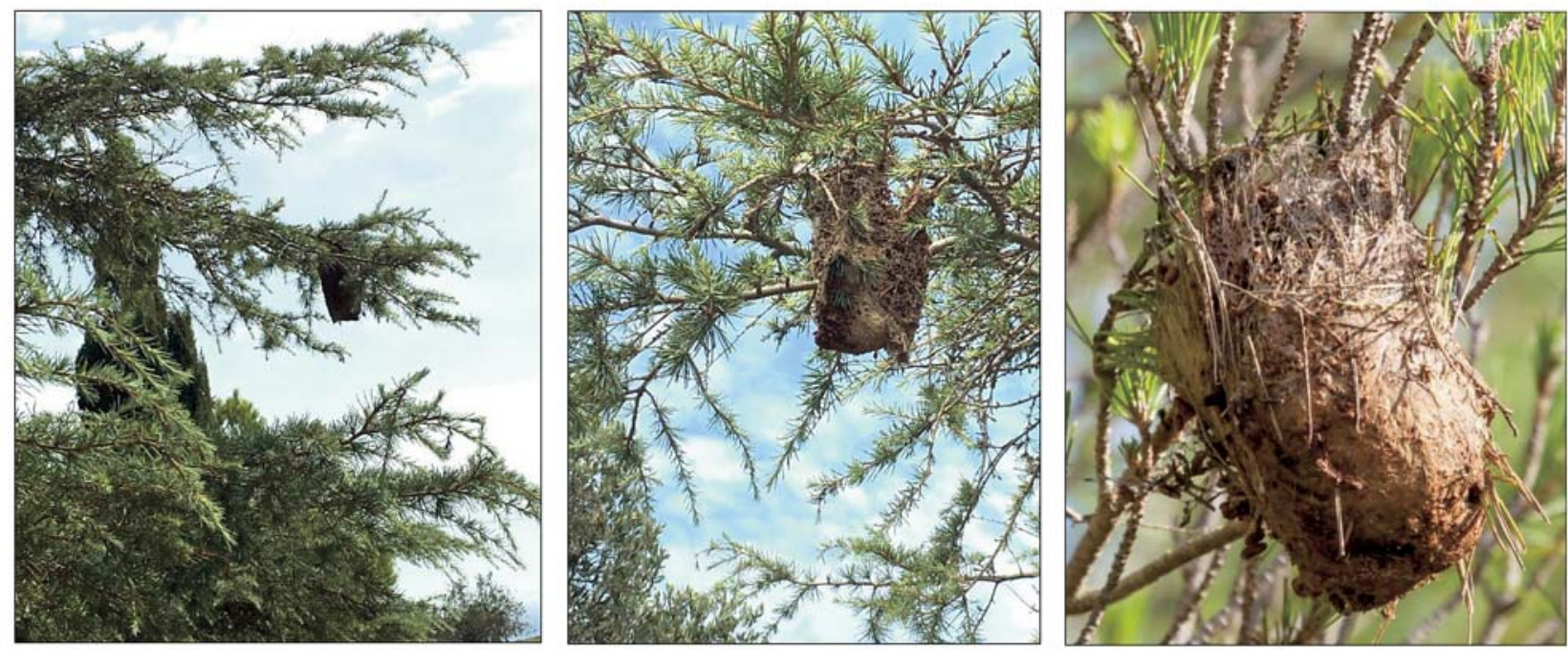

Fig. X - Thaumetopoea mediterranea: winter nests.

sunlight during the autumn and winter. Nests are generally small (length $14.2 \mathrm{~cm}$; width $5.5 \mathrm{~cm}$ ) with 28-46 mature larvae inside. In winter larvae can be observed outside of nests during days with mild temperatures. In 2017, the first larvae emerging in procession were recorded during the second week of February, the latest migrant larvae were observed in late April. The highest number of larvae was recorded in late March.

PuPA (Fig. IX, 3 and 4) - The pupa is formed inside an oval silk cocoon below ground and is of a whitish-brown colour. The obtected pupae are about 18-20 $\mathrm{mm}$ in length, oval, and of a pale red-brownish colour that later changes to dark reddish-brown. The cremaster is bluntly rounded, with two robust curved spines.
Flight ACTIVITY OF ADUlTs (Fig. XI) - On Pantelleria Island a total of 327 male were captured in the pheromone trap devices, during 2016-2017. In 2017 the flight of $T$. mediterranea males started in the second week of July (14 July) and ended after the second week of October. The highest number of adults was recorded in the first week of September and mid-September.

\section{DIAGNOSIS T. pityocampa, T. hellenica and T. mediterranea}

As already stated, among T. pityocampa, T. hellenica and T. mediterranea there are genetic differences. Morphologically the three species are closed each other, but can be

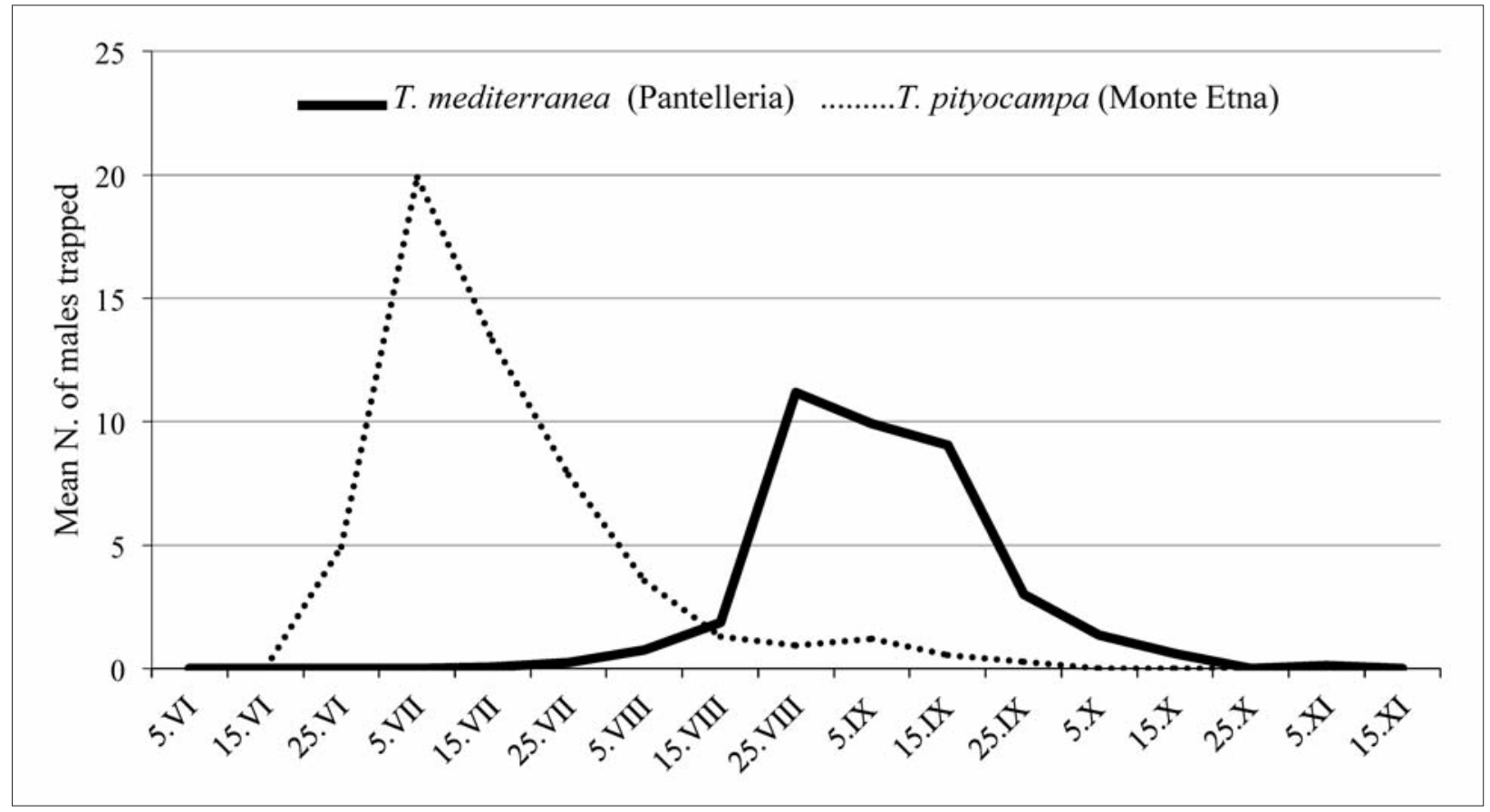

Fig. XI - Flight activity of male adults of T. mediterranea in Pantelleria Island (Italy); flight activity of male adults of T. pityocampa at Monte Etna (Sicily). 

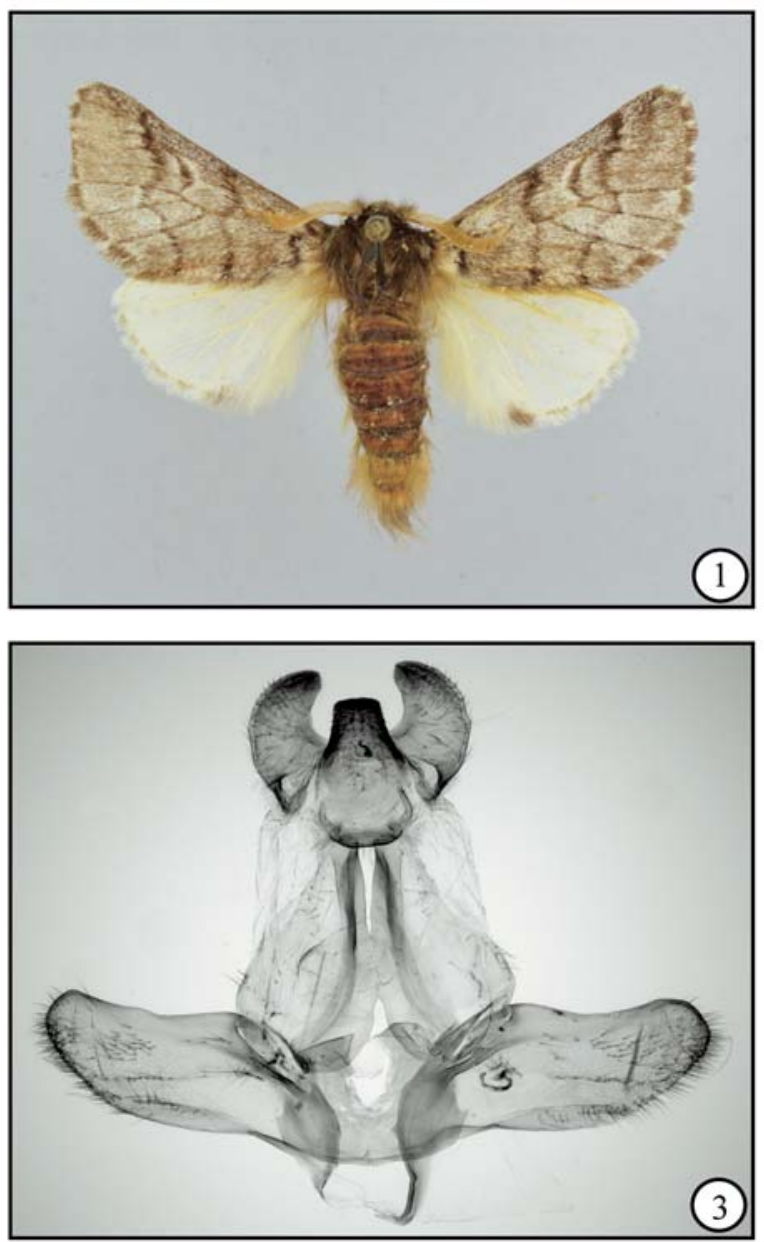

differentiated by their wing patterns and the forms of the canthus, mainly in male genitalia (in shape of gnathos, valvae and juxta) and also in female genitalia (in sterigma and subgenital sternite).

Comparing the wing pattern of the three species it is possible to note that in T. mediterranea there is more marked and evident, black colour, with bigger anal spot on hindwings. Discocellular spot of T. pityocampa is more close to distal margin than in the other two species. Transverse bands are more thin in T. mediterranea. Median band is interrupt in T. hellenica and complete in T. pityocampa and T. mediterranea (Fig. II, 1; Fig. VIII, 1; Fig. XII, 1).

The frontal process of T. pityocampa, T. hellenica and $T$. mediterranea have five teeth, the upper one is smaller in $T$. mediterranea (Fig. II, 2; Fig. VIII, 2; Fig. XII, 3).

In male genitalia of T. mediterranea, the uncus is longer than gnathos; the gnathos in T. mediterranea is sub-triangular, ear-shaped and is longer than wide, while in $T$. pityocampa the gnathos is broad, bean-shaped or even semi-circular. Valva almost elongated and narrows in T. hellenica, and compared to $T$. pityocampa the valva in T. mediterranea is bigger. T. mediterranea has the aedeagus bigger and broader than that of T. hellenica and T. pityocampa. Shape of juxta is sub-rectangular, longer than wide, while in T. hellenica, it is subrectangular, wider than long in T. mediterranea. Juxta of $T$. pityocampa is sub-triangular. Proximal margin hollowed, in T. hellenica and T. mediterranea, less so in T. pityocampa. It is shield-shaped, with proximal margin stretched to the angles in T. pityocampa and T. hellenica (Fig. II, 3; Fig. VIII, 3; Fig. XII, 3).
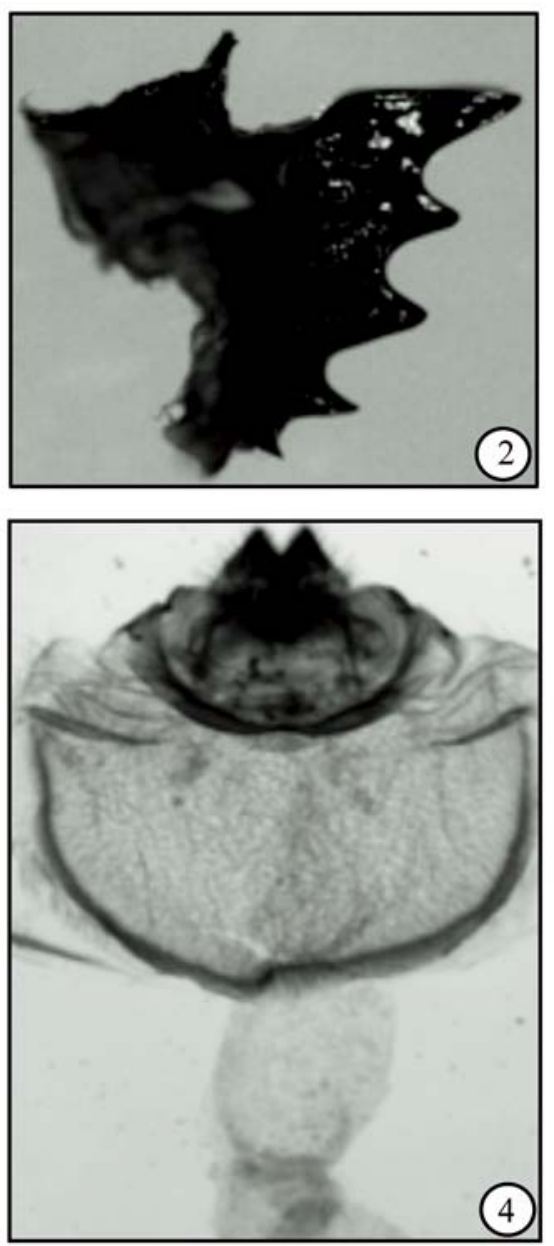

Fig. XII - Thaumetopoea pityocampa: adult (1); frontal process of male (canthus) (2); male genitalia (3); female genitalia (4).
Morphological characteristics of female genitalia in $T$. pityocampa, T. hellenica and T. mediterranea have not yet been illustrated and studied. In the three species the papillae anales are small and the apophyses short. The subgenital sternite has dense thorns and is covered with thin bristles especially in T. mediterranea. It is wide and distally concave in the three species, but in T. pityocampa two lateral transverse projections are present. Ductus bursae is not sclerotized. The sterigma in T. mediterranea is large, broad, with well-developed sinuous anteostial part, as opposed the semicircular shaped and narrow sterigma of $T$. hellenica and $T$. pityocampa. Characteristics of female genitalia need to be better considered in future researches (Fig. II, 4; Fig. VIII, 4; Fig. XII, 4).

In genetic characters, the distance of the T. hellenica Bin from that of T. mediterranea is equal to $3.05 \%$; the distance from $T$. hellenica and the nearest sequence of $T$. pityocampa deposited in GenBank is quite higher, being equal to $7 \%$. The distance from $T$. mediterranea and the nearest sequence of T. pityocampa deposited in GenBank is equal to $6 \%$ (TREMATERRA et al., 2017). The sequence of the holotype of the species $T$. mediterranea is identical to the sequence deposited in GenBank (accession number HE963113.1) belonging to the ENA clade of SimONATO et al. (2013) (see also AvTZIs et al., 2018).

Comparing egg batches, mature larvae and pupae those of T. hellenica are smaller than those of T. pityocampa. On the contrary, in $T$. mediterranea they are similar to those in $T$. pityocampa. In this respect, it is important to note that from the direct observations and data reported by various authors 
Table 1 - Thaumetopoea species, distribution range and host plants. Data from: AgENJo (1941), DogANLAR and AvCI (2001), Doganlar et al. (2005), Simonato et al. (2013), BATtisti et al. (2015), KerdelhuÉ et al. (2015), Basso et al. (2016), HaCKer (2016), TREMATERRA et al. (2017).

\begin{tabular}{|c|c|c|}
\hline Species & Distribution & Host plants \\
\hline T. apologetica & Eastern Africa & Maerua crassifolia \\
\hline T. cheela & Afghanistan, Pakistan, India & Rhus cotinus \\
\hline T. dhofarensis & Arabian Peninsula & \\
\hline T. herculeana & Europe, Middle East, India & $\begin{array}{l}\text { Cistus salviaefolius, Erodium moschatum, Erodium arborescens, } \\
\text { Helianthemum vulgare, Helianthemum croceum }\end{array}$ \\
\hline T. ispartensis & Turkey & Cedrus libani \\
\hline T. jordana & Northern Africa, Jordan valley & Rhus tripartita, Schinus terebinthifolium \\
\hline T. pinivora & Europe & Pinus spp. \\
\hline T. pityocampa & Europe, North Africa, Middle East & Cedrus spp., Pinus spp., Pseudotsuga spp. \\
\hline T. processionea & Europe, Middle East & Quercus spp. \\
\hline T. sedirica & Turkey & Cedrus libani \\
\hline T. solitaria & Europe, Middle East & $\begin{array}{l}\text { Cupressus sempervirens, Fraxinus spp., Pistacia palaestina, Pistacia } \\
\text { terebinthus, Pistacia atlantica, Pistacia vera, Rhus spp., Schinus spp. }\end{array}$ \\
\hline T. torosica & Turkey & Pinus brutia \\
\hline T. wilkinsoni & Middle East & Cedrus spp., Pinus spp. \\
\hline
\end{tabular}

in different European locations, the data provided on T. pityocampa are variable (MIRCHEV et al., 2015).

Comparing flight period of $T$. hellenica (in Greece) and $T$. pityocampa (in Petacciato, Italy) it is noted that flight period of the first species is delayed, with adults of T. hellenica observed from early August to late October and early November, while T. pityocampa were found from late Julyearly August to mid September (Fig. VI). With regards to the flight of T. mediterranea (in Pantelleria Island) and T. pityocampa (in Pitarrona, on Monte Etna) it is noted that flight period of first species is delayed, with males of T. mediterranea trapped in the second week of July (14 July) and lasted after the second week of October. On Monte Etna, the flight period of $T$. pityocampa males started on 15 June and lasted until the fall in September (Fig. XI).

As in other Thaumetopoea species (Table 1), also T. hellenica and T. mediterranea build winter nests on external parts of trees. T. mediterranea nests are smaller than those of T. pityocampa and T. hellenica. T. hellenica colonize Pinus halepensis and probably also P. brutia plants; T. mediterranea colonize Cedrus deodara, Pinus pinaster and Pinus pinea.

Comparing T. hellenica (in Greece) and T. pityocampa (in Petacciato, Italy) winter migration of emerging larvae period, it is possible to note that migration period of $T$. hellenica larvae is advanced in comparison to T. pityocampa. Larvae of $T$. hellenica have been observed in February and in March, while T. pityocampa were found from the end of March till the last week of April. Comparing T. mediterranea (in the Pantelleria Island) and T. pityocampa (on the Monte Etna) migration larvae period, it is possible to note that migration period of $T$. mediterranea is advanced with larvae observed in February and in March, while T. pityocampa were found from late March to late April.

\section{ACKNOWLEDGMENTS}

The authors wish to thank Dr. Paul Sammut (Rabat, Malta), Prof. Christos Athanassiou (University of Thessaly, Greece), Prof. Nickolas Kavallieratos (University of Athens, Greece), and Prof. Santi Longo (University of Catania, Italy) for suggestions and sending part of data and specimens of Thaumetopoea. The current investigation was partially funded as part of the LIFE-PISA project (LIFE13 ENV/ ES/000504) from European Union.

\section{REFERENCES}

Agenjo R., 1941 - Monografia de la familia Thaumetopoeidae (Lep.). - Eos, 17: 69-130.

Athanassiou G.C., Kavallieratos N.G., Pardo D., Sancho J., Colacci M., Boukouvala M.C., Nikolaidou A.J., Kondodimas D.C., Benavent-Fernández E., GÁlveZ-Settier S., Trematerra P., 2017 - Evaluation of pheromone trap devices for the capture of Thaumetopoea pityocampa (Lepidoptera: Thaumetopoeidae) in southern Europe. - Journal of Economic Entomology, 110 (3): 1087-1095.

Avtzis D.N., Petsopoulos D., Memtsas G.I., Kavallieratos N.G., Athanassiou C.G., Boukouvala M.C., 2018 - Revisiting the distribution of Thaumetopoea pityocampa (Lepidoptera: Notodontidae) and T. pityocampa 
ENA Clade in Greece. - Journal of Economic Entomology, XX (X): doi: 10.1093/jee/toy047

Basso A., Simonato M., Cerretti P., Paolucci P., Battisti A., 2016 - A review of the "summer" Thaumetopoea spp. (Lepidoptera: Notodontidae, Thaumetopoeinae) associated with Cedrus and Pinus. - Turkish Journal of Forestry, 17 (special issue): 31-39.

Battisti A., Avci M., Avtzis D.N., Ben JamaA M.L., Berardi L., Berretima W., Branco M., Chakali G., El Alaoui El Fels M.A., Frérot B., Hódar J.A., IonescuMĂLĂNCUS I., İpekdal K., LARSSON S., MANOLE T., Mendel Z., Meurisse N., Mirchev P., Nemer N., Paiva M.R., Pino J., Protasov A., Rahim N., Rousselet J., Santos H., SAuvard D., Schopf A., Simonato M., Yart A., Zamoum M., 2015 - Natural History of the Processionary Moths (Thaumetopoea spp.): New Insights in Relation to Climate Change. In Roques A (Ed) Processionary Moths and Climate Change: An Update. - Springer, Orleans: 15-79.

Colacci M., Kavallieratos N.G., Athanassiou C.G., Boukouvala M.C., Rumbos C.I., Kontodimas D.C., Markoyannaki-Printziou D., Pardo D., Sancho J., Benavent-Fernández E., Gálvez-Settier S., SciarRetTA A., Trematerra P., 2018 - Management of the pine processionary moth, Thaumetopoea pityocampa (Lepidoptera: Thaumetopoeidae), in urban and suburban areas: trials with trunk barrier and adhesive barrier trap devices. - Journal of Economic Entomology, 111: 227-238 (doi: 10.1093/jee/tox270)

Doganlar M., Avci M., 2001 - A new species of Traumatocampa Wallengren (Lepidoptera: Thaumetopoeidae) feeding on cedar from Isparta (Türkiye). Turkiye Entomoloji Dernegi, 25 (1): 19-22.

Doganlar M., Doganlar O., Doganlar F., 2005 - Morphology and systematics of European species of Traumatocampa Wallengren, 1871 with descriptions of two new species from the Mediterranean region of Turkey (Lepidoptera, Thaumetopoeidae). - Entomofauna, 26 (13): 229-240.
HACKer H., 2016 - Systematic and illustrated catalogue of the Macroheterocera and superfamilies Cossoidea Leach, [1815], Zygaenoidea Latreille, 1809, Thyridoidea Herrich-Schäffer, 1846 and Hyblaeoidea Hampson, 1903 of the Arabian Peninsula, with a survey of their distribution (Lepidoptera). - Esperiana, 20: 147-149.

HaJibabaei M., Janzen D.H., BuRns J.M., Hallwachs W., HEBERT P.D.N., 2006 - DNA barcodes distinguish species of tropical Lepidoptera. - PNAS 2006, 103: 968-971.

Kerdelhué C., Battisti A., Burdan C., Branco M., Cassel Lundhagen A., İpekdal K., Larsson S., LopeZ Vaamonde C., Magnoux E., Mateus E., Mendel Z., Negrisolo E., Paiva M.R., Pivotto I.D., Rocha S., RonnÅs C., RoQues A., Rossi J.P., Rousselet J., SAlvato P., Santos H., Simonato M., Zane L., 2015 - Genetic diversity and structure at different spatial scales in the processionary moths. In Roques A (Ed) Processionary Moths and Climate Change: An Update. - Springer, Orleans: 227-263.

Mirchev P., Dautbasic M., Mujezinovic O., Georgiev G., GEORGIEVA M., BoyadzhIEV P., 2015 - Structure of Egg Batches, Hatching Rate and Egg Parasitoids of the Pine Processionary Moth. Thaumetopoea pityocampa (Denis and Schiffermüller, 1775) (Lepidoptera: Notodontidae), in Bosnia and Herzegovina. - Acta Zoologica Bulgarica, 67 (4): 579-586.

RATnASIngham S., HeBerT P.D.N., 2007 - BOLD: The Barcode of Life Data System (www.barcodinglife.org). Molecular Ecology Notes, 7: 355-364.

Simonato M., Battisti A., Kerdelhué C., Burban C., Lopez-Vaamonde C., Pivotto I., Salvato P., Negrisolo E., 2013 - Host and Phenology Shifts in the Evolution of the Social Moth Genus Thaumetopoea. - PLoS ONE, 8 (2): e57192. Doi: 10.1371/journal.pone.0057192.

Trematerra P., Scalercio S., Colacci M., 2017 Thaumetopoea hellenica $s p$. $n$. and Thaumetopoea mediterranea $s p$. n. new taxa from Southern Europe (Lepidoptera, Notodontidae, Thaumetopoeinae). - Redia, 100: 3-10. http://dx.doi.org/10.19263/REDIA-100.17.01 